\title{
PARA AlÉm do PRincíPIo de ORdenAÇÃo: MARQUÊS DE SADE E ARTHUR BISPO DO ROSÁRIO
}

\author{
Beyond the organization's principle: \\ Marques de Sade and Arthur Bispo do Rosário
}

\author{
Rodrigo Guimarães Silva*
}

Mais, ainda. "Estou convencido que se pode ir mais longe ainda do que tudo isto", diz o libertino Curval em Os 120 dias de Sodoma, após escutar a narrativa da personagem Duclos sobre as extravagâncias sexuais de seu cliente. Nos textos do Marquês de Sade há sempre a escansão do excessivo, das infindáveis operações de adição e de multiplicação, da operação hiperbólica do "mais". Sade, logo nas primeiras páginas de $O S$ 120 dias, convida (e adverte) o leitor "para o relato mais impuro já feito desde que o mundo existe, pois não há livro semelhante nem entre os antigos nem entre os modernos" (SADE, 2006, p. 62).

Esse "mais impuro" sadiano não é do tipo "triunfante", que se afirma pelo desapreço do outro. Trata-se do mais do excesso, que não estabelece com a "regra" um contraponto típico dos sistemas duais de oposição simples. Por isso que apresentar Sade como um expoente da corrente materialista do século XVIII, em oposição à linhagem sentimental de Rosseau, ainda é dizer pouco. Nomear os contrários - regra versus exceção - não nos possibilita situar o corte executado pelo gume do excesso sadiano, que singulariza, de forma irredutível, a maneira de sangrar o estereótipo e as convenções, ao mesmo tempo em que abre a ferida não impossibilitadora da pavimentação da escrita literária em modelos genéricos. A beleza, diz o narrador de Os 120 dias, "é coisa simples, a fealdade é que é coisa extraordinária e todas as imaginações ardentes sempre preferem, sem dúvida, uma coisa extraordinária em termos de lubricidade a uma coisa simples" (SADE, 2006, p. 47).

Não só em sua época, mas ainda hoje, Sade é visto como um autor excessivo. O seu próprio texto propõe esse mais ainda, o incessante transpassamento das instâncias que se normificam e acolhem desejos cicatrizados, cuja energia sexual, observou Octavio Paz, é confiscada e

- Unimontes. 
regulamentada pela sociedade.

Tanto André Breton quanto seus pares do movimento surrealista entronizaram Sade "como a expressão extrema e desmesurada do desejo humano” (MORAES, 2006, p. 116). Em Os 120 dias, o narrador expõe e justifica a necessidade de seu sistema se pautar pelo transbordamento:

Sem dúvida, muitos dos desregramentos que encontrarás aqui retratados desagradar-te-ão; alguns entretanto aquecer-te-ão a ponto de te custarem porra, e isto nos basta. [...] Esta é a história de uma magnífica refeição em que seiscentos pratos diversos serão oferecidos a teu apetite. Apreciarás todos? Não, sem dúvida! Mas esse número prodigioso ampliará os limites de tua escolha, e, encantado por esse aumento de faculdades, não te atrevas a repreender o anfitrião que te presenteia. [...] Acerca da diversidade, estejas assegurado de que ela é precisa; estuda bem as paixões que te parecem assemelhar-se a outra sem a menor diferença, e verás que essa diferença existe e, por mais leve que seja, ela apenas tem esse refinamento, essa delicadeza que distinguem e caracterizam o gênero de libertinagem aqui tratado (SADE, 2006, p. 62-63).

Essa imensa variedade de iguarias que Sade oferece em seu banquete, de forma minuciosa, para a degustação do leitor, forma uma pluralidade incoercível a toda unidade, assim como observou Octavio Paz em Um mais além erótico: Sade. Em outras palavras, a particularidade é um dos princípios da proposição do marquês, daí a necessidade do libertino de recorrer ao detalhamento obsessivo a fim de que possa destacar ainda mais as insígnias da diferença, os "caprichos". Assim, o texto de Sade encarna a fórmula de Pierre Soury: do semelhante ao mesmo, há lugar para uma diferença. Ao se apropriar desse olhar, também obsedado pela compulsão de discriminação e de rastreamento do irrepetível, o leitor se vê capaz de atravessar a muralha das repetições do marquês sem que o livro caia das mãos. É frequente, por parte dos críticos das obras de Sade, assinalar a monotonia de seu texto, as repetições infindáveis que acabam por causar o cansaço e a irritação do leitor. A esse respeito, diz Octavio Paz: "Tudo nele é imenso e único, inclusive as repetições. Por isso nos fascina e alternadamente nos atrai e nos repele" (PAZ, 1999, p. 116).

Até mesmo na maneira de narrar, muitas vezes Sade repisa a mesma matriz de pensamento, martela o mesmo significante: "Ele é muito rico, muito fidalgo, muito rígido e muito cruel". Ou ainda: "o corpo mais lindo do mundo, o rosto mais nobre, mais agradável, mais interessante, todos os atrativos enfim, os que mais agradam, tornados mais acentuados ainda". A sequência enfadonha de "muito" e de "mais" não é um "defeito" de estilo ou um simples artifício retórico, pois o próprio sade alerta o leitor quanto às suas repetições que abrigam pequenas variações, como foi visto na citação anterior.

A reiteração abusiva de ideias também ocorre com seus personagens 
libertinos que, mesmo em diferentes romances, assumem posições filosóficas muito semelhantes. Daí a afirmação de Octavio Paz, em um tom bem menos benevolente, que Sade não constrói personagens, e sim conceitos ${ }^{1}$.

Mas como conciliar a proposta libertina, que afirma não admitir limite algum, com o ritornelo das formas enunciativas e as repetições argumentativas dos personagens sadianos? Se "um excesso sempre conduz ao outro", tal como postula Curval em Os 120 dias, e a lei do excesso é "exceder-se a si mesmo", como conceber os desvarios eróticos de quatro libertinos, as suas "desordens de gostos e caprichos" regulamentadas por um rigoroso plano de execução de tarefas que deve ser levado a termo no afastado castelo de Silling?

O regime é de "aquartelamento", a disciplina, ascética, e os horários para o desjejum e os "trabalhos do dia" são inflexíveis. Em Os 120 dias, Sade "gasta" dez páginas apenas para descrever o regulamento a que todos, inclusive os libertindos, devem se submeter. Os súditos são divididos rigorosamente em classes: meninos, meninas, fodedores, criadas, cozinheiras, esposas e narradoras. Essa "comitiva" atende, de forma absoluta, os mais perversos desejos dos quatro libertinos: Curval, Durcet, Blangis e o Bispo. Respondendo a um Programa que impõe cinco modalidades de vícios ao dia, no final da empreitada, deve-se realizar 600 paixões.

Eliane Robert Moraes elucida, com destacada acuidade crítica, os propósitos do Programa e da aritimética do marquês. Segundo a autora, "a contabilidade do quarteto de Silling" opera com uma "prodigiosa quantidade de algarismos, sinais, medidas, listas e toda sorte de cálculos [...] A enumeração sadiana visa explicitar as cifras do gozo. [...] Por certo, a quantidade evoca a abundância, o luxo, o poder e outras figuras da riqueza" ${ }^{2}$.

Eliane Robert acentua também que todo esse processo de inventariar, enumerar e catalogar está relacionado com a recusa radical do sentimento amoroso, já que as operações aritméticas são responsáveis pela indiferenciação do sujeito: rostos são transformados em números, corpos são intercambiáveis por cifras, e as histórias pessoais são transpostas para os obsessivos pormenores que compõem a cena erótica em uma combinatória infindável que garante e maximiza a "rentabilidade do sistema" até o imponderável, qual seja, alcançar os marcos inatingíveis de um mais-gozar. Sob essa ótica, o entulhamento de cifras, números, processos de

${ }^{1}$ Pode-se evocar aqui os "personagens conceituais" de Gilles Deleuze, que são operadores textuais que movimentam o texto filosófico. Em Um mais além erótico: Sade, Octavio Paz reúne três textos publicados em diferentes épocas. O primeiro é um poema escrito em 1947, logo após o seu contato com a obra de Sade. O tom é laudatório, eufórico, como reconhece Paz: "Eu o li com assombro e horror, com curiosidade e desagrado, com admiração e reconhecimento." Já em 1960, Paz escreve um ensaio em que o distanciamento necessário comparece, embora ainda a dicção seja eufórica. O mesmo não acontece em seu último texto de 1986, em que se evidencia uma acirrada crítica em relação à obra sadiana.

${ }^{2}$ Prossegue Eliane Robert: "De fato, a amplitude da dilapidação que está no horizonte das atividades da libertinagem supõe reservas sem fim, sejam elas de dinheiro, de energia, de corpos, ou do que mais for necessário para sua plena realização. Mas, uma vez contabilizadas, as somas esbanjadas em função do gozo físico são repostas em um plano simbólico que opera significativa inversão de sinais: o que foi dilapidado torna-se então objeto de acumulação." (Cf. SADE, 2006, p. 10). 
quantificação dos "produtos" responde a um propósito bem delimitado: levar ao deslimite não apenas o prazer físico, mas o "gozo filosófico" do devasso. Por isso é necessária a frequente mudança de registro e o estabelecimento de um Programa eficiente de regras e condutas, pois após "perder porra" e o corpo se encontrar extenuado, o libertino pode prolongar sua lubricidade com os prazeres da gastronomia ou com a volúpia filosófica proporcionada pelas cenas de crueldade. E mais: pela atividade intelectual da "fera pensante" caucada no deboche e nos processos de demolição dos valores culturais, sobretudo os morais e os religiosos.

O dispositivo filosófico como forma de potencializar o gozo constitui um diferencial marcante no pensamento de Sade em relação aos modelos hedonistas, que propõem a realização "imediata" do desejo. É preciso saber comandar e postergar a volúpia, organizar a economia dos arranjos. Diz Curval: "a porra nunca deve ditar nem dirigir os princípios; cabe aos princípios regular a maneira de perdê-la” (SADE, 2006, p. 266).

As operações econômicas de acúmulo e descarga vigoram com autoridade axiomática no sistema de Sade. Mas a equação de polarizar a energia sexual para depois despolarizá-la se complexifica ainda mais com a entrada do elemento reflexivo e do recurso narrativo como forma de extrair o máximo do ilimitado do desejo. Por isso que Simone de Beauvoir em Novelas do marquês de Sade sublinha que o erotismo na obra do marquês realiza-se não pela crueldade, mas pela literatura. Observação caucionada pela voz do narrador em Os 120 dias quando afirma: "Entre os verdadeiros libertinos, admite-se que as sensações comunicadas pelo órgão do ouvido são as que mais agradam e deixam as mais vivas impressões" (SADE, 2006, p. 36). Esta é a função das quatro narradoras no castelo de Silling, produzir um mais-gozar pelo relato, ampliar os excessos mediante gradientes de detalhamentos. Como se vê em algumas passagens de Os 120 dias, em que o narrador destaca a supremacia do relato sobre o acontecimento: "Desgranges anuncia que vai falar de assassinatos e traição, nos quais a maneira é o ponto principal e o efeito, isto é, o assassinato é apenas acessório" (SADE, 2006, p. 334).

Para tanto, é necessário estabelecer um princípio de ordenação e um Plano para cada mês a fim de graduar o desregramento até o ápice, qual seja, o último mês, pois, como é de se supor, tais excessos "levam ao assassinato", à queima da mercadoria.

Assim, o princípio de ordenação constitui o alicerce do Projeto do marquês mediado pelo gesto reflexivo e pela palavra literária, propiciando a "ordem na desordem", uma forma de restabelecer o equilíbrio em um sistema que propõe, explicitamente, a transgressão de todas as instâncias. Porém, essa subversão absoluta é apenas aparente.

Há, entre os libertinos, um acordo tácito, e a ordem estabelecida é com o propósito de sua "futura devastação". No castelo de Silling, o aniquilamento total diz respeito apenas aos códigos morais socialmente estabelecidos, e não em relação às normas autoimpostas pelos devassos. 
Todas as lubricidades são permitidas, "salvo, contudo, as que poderiam prejudicar a ordem do arranjo feito para as deflorações, a qual haverá de ser sempre rigorosamente respeitada" (SADE, 2006, p. 57).

o "salvo" sadiano é o que possibilita a equilibração do sistema. Diferentemente de Dostoievski que, em seu conto Bobok, desenvolve a ideia de que não existindo Deus nem a imortalidade da alma "tudo é permitido", o "salvo" de Sade ascende, em certos momentos, à instância de Lei. Dito de outra forma, um sistema que se sustenta pela contravenção não pode prescindir do Outro, seja na esfera social, seja em sua dimensão simbólica (ainda que esse Outro coloque o libertino numa posição de "absoluta dependência e de infinita mobilidade”, como acentou Octavio Paz). A necessidade das topologias, das demarcações de fronteiras é inerente ao modelo do marquês. Mesmo um ermitão, como Minski, em Histoire de Juliette, que se isolou em uma ilha e vê a si mesmo como "poderoso o suficiente para não precisar de ninguém", necessita do Homem para detestálo, "para desafiar sua censura", pulverizar todos os seus cultos e governos (MORAES, 2006, p. 21).

Minski afirma ser feliz em seu "pequeno domínio". Esse "ilhamento" é uma constante nas diferentes obras de Sade. As práticas de lubricidade acontecem sempre entre quatro paredes: ora num mosteiro ermo, ora na alcova ou no porão de uma casa. O Marquês sabia que a "Sociedade dos Amigos do Crime" só era viável em um espaço confinado. E ao estabelecer "domínios", é necessário manter vivo o fora (Deleuze) o inimigo e a utopia de exilar o que dentro se enraíza: os processos de enrijecimento simbólico. Por isso que a virtuosa Justine, ao se deparar, ao longo de toda a sua vida, com dezenas de libertinos, e ter sido presa, escravizada e violentada por eles, sempre escapa por vias improváveis, para no final do romance ser morta de forma inteiramente gratuita: por um raio. Apenas a Natureza poderia matar Justine. A razão é simples: Sade, decerto, "ama” Justine, justamente por odiá-la tanto ${ }^{3}$.

o que fascina no sistema sadiano não é fazer do erotismo o motor do mundo ou pensá-lo como "a realidade" (Octavio Paz), e sim conseguir converter todos os índices e objetos, inclusive os repulsivos, em utensílios de prazer. Essa utensilidade da existência só foi possível graças a um mecanismo que, somente um século depois, foi identificado por Freud. Trata-

\footnotetext{
${ }^{3}$ A propósito da importância conferida por Sade em relação à natureza, assinala Octavio Paz: "Com a mesma insistência com que os teólogos recorrem a Deus, Sade invoca a natureza, o motor supremo, a causa das causas. Uma causa que destrói a si própria porque tudo está em perpétua mudança. [...] Nada é necessário na natureza, salvo o movimento (o que equivale a dizer que nada possui significação por si, exceto a contingência natural" (Cf. PAZ, 1999, p. 67-68). As consequências filosóficas de aceder a Natureza a uma espécie de metafísica, observa Paz, é de naturalizar todos os seus gestos de união, dispersão e reunião de seus elementos. Em outras palavras, o crime, nesse contexto, não tem realidade em si, pois não passa de um desarranjo da matéria, um movimento natural incapaz de ultrapassar a própria natureza. A moralidade antropomórfica que advoga "o homem como medida de todas as coisas", também fica abalada diante de uma natureza completamente indiferente quanto à extinção ou à perpetuação da humanidade.
} 
se do "entrelaçamento" da pulsão de destruição com o impulso sexual de preservação da vida: o par Eros-Thanatos, ou, no contexto sadiano, a parelha prazer-dor, de onde se depreende que erotismo, em muitas de suas dimensões, é rasgado pela violência e a transgressão. A racionalidade do sistema de Sade (a ordem da desordem) consiste em preservar o elemento repulsivo e estabelecer com ele uma relação de cumplicidade ou mesmo alterar o seu sinal afetivo: "O Duque, entretanto, em razão da enormidade de sua constituição e, sem dúvida, antes por crueldade do que por gosto, ainda metia em bocetas com o maior prazer" (SADE, 2006, p. 30) ${ }^{4}$.

Outras vezes, o objeto aversivo não é positivado, e sim delimitado como território interdito à maneira de um corpo sólido que restringe a liberdade de movimento. Decorrem daí regras e estatutos, tais como o da Sociedade dos Amigos do Crime, que prescreve tanto as ações obrigatórias quanto o rosário de "nãos" pelo qual o associado deve se pautar. Esse paroxismo que entrelaça os desregramentos que a lubricidade exige, com um regime de ditames totalitários, perpassa muitas das obras de Sade. Os receituários das evitações sempre comparecem, como se evidencia na fala do narrador em Os 120 dias a respeito dos preceitos para um homem ser feliz: "Um homem somente havia de se entregar a todos os vícios, sem nunca se permitir virtude alguma, pois não se tratava apenas de sempre fazer o mal, como também de nunca fazer o bem" (SADE, 2006, p. 20) ${ }^{5}$.

Em suma, o par eros-thanatos utiliza-se dos materiais (corpos humanos, raramente animais) sem destruí-los completamente. Percebe-se uma "logicidade" que atua no sentido de manutenção do sistema, como se vê em Os 120 dias, no balanço das atividades da jornada. Na contabilização dos excessos, nem todas as "vítimas" foram sacrificadas. Dos 46 integrantes da comitiva, 30 foram imolados, sendo que os outros 16 foram levados de volta à França. Dessa forma, a pulsão de destruição nunca é exercida em toda a sua amplitude, porque se assim ocorresse, os próprios libertinos acabariam por se exterminarem.

Os depravados, nos romances de Sade, sempre preservam uma relação de camaradagem entre eles, elemento inverossímil, considerando que o embate frontal nunca se estabelece entre "os amigos". Outra questão que também surpreende nos devassos do marquês é a ausência completa do conflito, do remorso e da culpa, pois um libertino "não detesta de manhã o que fez à noite" ${ }^{6}$. Esse é um ponto que difere radicalmente os personagens

${ }^{4}$ Já as vítimas dos libertinos não conseguem transformar o afeto negativo em positivo, restando-lhes apenas a aceitação do "mal menor", tal como se evidencia nos regulamentos aos quais estão sujeitos os súditos do castelo de Silling: "Não que tenhais muito a ganhar com essa conduta, mas teríeis muito a perder não a respeitando" (SADE, 2006, p. 60).

${ }^{5}$ Em uma versão similar, presente em A filosofia na alcova, o personagem Dolmancé atesta: "Nem sempre se pode fazer o mal. Privados do prazer que nos proporciona, temos de ao menos tentar equivaler esta sensação com a pequena e picante maldade de jamais fazer o bem" (SADE, 2003, p. 45).

${ }^{6} \mathrm{Em}$ A filosofia na alcova, o personagem Dolmancé questiona: "Que me dizeis do remorso, meu amigo? Poderá existir na alma dos que não vêem crime em nada?” (SADE, 2003, p. 173). 
libertinos dos romances de Sade em relação ao personagem Maldoror, de Lautréamont. A tensão interna, a insônia, o conflito, a luta contras as vozes da consciência são uma constante em Maldoror. O personagem humanomítico de Lautréamont é igualmente convicto no mal, mas a sua luta contra o arrependimento, a voz da consciência, o censor severo, é sem fim. Maldoror, ao contrário dos libertinos "estóicos" de Sade, está sempre atormentado por pensamentos sombrios: "Quem, pois, sobre minha cabeça, desfere golpes com uma barra de ferro, como um martelo batendo na bigorna?" (LAUTRÉAMONT, 2005, p. 84) ${ }^{7}$.

Enquanto Maldoror luta eternamente contra Deus numa batalha em que não há vencedor e nem vencido, os devassos de Sade negam sua existência mediante um ateísmo extremo ${ }^{8}$. Embora evoquem constantemente o nome de Deus, sobretudo nos momentos em que gozam, o propósito dos personagens sadianos é sempre de obter algum ganho para a economia do sistema psíquico, pois as blasfêmias ("Porra de Deus"; "Deus sagrado e fodido"; "pela morte de Deus") funcionam como "pequenas cerimônias", acessórios para inflamar a volúpia. Mas "desde o instante em que não há mais Deus, de que serve insultar seu nome?", indaga o libertino Dolmancé em A filosofia na alcova. A resposta a essa questão é fornecida por ele mesmo: "[...] é essencial pronunciar palavras fortes ou sujas na embriaguez do prazer, e as de blasfêmia são muito úteis à imaginação" (SADE, 2003, p. 78).

Por vezes, os excessos no sistema sadiano se complexificam ainda mais. Para que o homem, máquina de crueldade e prazer, possa alcançar plena autonomia em relação ao seu objeto de gozo, é necessário abstraí-lo ao máximo e se instalar no imaginário, o lugar do mais-gozar por excelência, do espaço literário que joga com a (ir)realidade dos fantasmas que criam a devassidão ${ }^{9}$. Mas Sade, em vez de estar à mercê dos processos de fantasmagorizações, sempre preserva sua autoria, mesmo que para isso seja necessário sacrificar o relato, degenerá-lo em enumeração. Em Os 120 dias, por exemplo, não há, ao narrar, cenas pormenorizadas dos três últimos meses, apenas um catálogo de aberrações que sinalizam, em muitos

\footnotetext{
${ }^{7}$ Em outra passagem, Maldoror diz: "A consciência julga severamente nossos pensamentos e nossos atos mais secretos, e não se engana. Como ela é, freqüentemente, impotente para prevenir o mal, não pára de acossar o homem como a uma raposa, principalmente na escuridão" (LAUTRÉAMONT, 2005, p. 153).

${ }^{8}$ Há exceções, como personagens que afirmam a existência do Criador, porém trata-se de um Deus que representa o mal absoluto.

${ }^{9} \mathrm{O}$ licencioso Curval, no castelo de Silling, expóe seu pensamento que, de certa forma, anula o objeto: "Não é no gozo que consiste a felicidade, é no desejo, é rompendo os freios que a ele se opõe. Ora, será que tudo isso se encontra aqui, onde apenas preciso desejar para ter? Juro, acrescentou, que, desde que aqui estou, minha porra não correu uma única vez para os objetos que aqui estão; apenas se derramou para aqueles que não estão aqui. E, por sinal", acrescentou o financista, "a meu ver, falta uma coisa essencial à nossa felicidade: o prazer da comparação, prazer que não pode nascer senão do espetáculo dos infelizes, e não vemos nenhum aqui. É da visão de quem sofre e não goza daquilo que tenho que nasce o charme de poder se dizer: portanto, sou mais feliz do que ele" (Cf. SADE, 2006, p. 142).
} 
momentos, o poder absoluto do imaginário em relação a qualquer fração, por menor que seja, de realidade. Decorre daí a cifragem cada vez mais impraticável das perversões propostas. Se no primeiro mês as fantasias extravagantes como "comer fetos de abortos" eram relatadas, no segundo mês, os números precedem às prescrições ainda mais absurdas: "61. Ele manda uma moça nua montar a cavalo sobre um grande crucifixo; ele fode sua boceta de quatro, nessa atitude, e de modo que a cabeça de Cristo masturbe o clitóris da puta". Ou ainda, constam no Projeto relacionamentos sexuais com cadáveres, comer chouriço de sangue humano, matar a filha na frente de sua mãe, e outros planos inquestionavelmente imaginários, tais como arrancar o coração de uma moça viva, fazer um buraco nele e "foder esse buraco". Em muitas passagens das prescrições que se seguem após o primeiro mês, Sade não deixa dúvidas de que suas propostas já não se inscrevem mais na realidade. Vejamos: "31. Ele fode uma cabra de quatro enquanto o açoitam. Ele faz um filho nessa cabra, que ele enraba por sua vez, embora seja um monstro".

Percebe-se o empobrecimento da forma de narrar, o esvaziamento do objeto erótico abstraído na enumeração, a acumulação vertiginosa das cifras sem, contudo, negar um componente irredutível: a imanência do corpo.

Toda a onipotência exercida pelos libertinos no castelo de Silling necessita do fechamento total de um domínio para absolutizar o desejo e seu campo de consumação. No entanto, das 600 paixões propostas pelo Plano, 598 foram narradas ou enumeradas. A falta, inexistente dentro de determinado domínio, o do Castelo, é denunciada de fora, quando o narrador evoca a incompletude das 150 paixões (que deveriam configurar o último mês): "148. A última. (Verificai por que essas duas faltam, todas estavam nos rascunhos) (SADE, 2006, p. 353 $)^{10}$.

A primazia do imaginário sobre os objetos da realidade também é tematizada em Justine: Os sofrimentos da virtude. Para o libertino Clement, "o único preço que os objetos têm é aquele a eles dado por nossa imaginação" (SADE, 1988, p. 134). Isso converte o objeto erótico em um signo variável, em "função" (no sentido matemático, como frisou Octavio Paz), o que equivale a dizer que nenhum objeto sadiano está em uma relação constante com o prazer (Lacan a propósito de Sade).

A submissão do gozo aos elementos da imaginação ("aguilhão dos prazeres"), possibilita o personagem do marquês construir um argumento em que a fantasia da mesa não é menos extraordinária do que a fantasia da cama; quer dizer, há uma legitimação de todas as fantasias em que o enquadre moral ou a unanimidade dos "gostos" perdem seu valor, restando apenas o critério das intensidades. Diante do exposto, verifica-se que as

\footnotetext{
${ }^{10}$ No encerramento da obra, encontram-se também estas curiosas "notas" em forma de lembrete e de repreenda: "Sobretudo, nunca fazei os quatro amigos fazerem nada que não foi narrado, e vós não tivestes este cuidado". Ou então, no final dos relatos do primeiro mês, verifica-se também uma lista, fora da obra, intitulada "Erros que cometi".
} 
paixões mais cruéis e abomináveis, as que têm que vencer uma resistência maior são as que conseguem fervilhar o gozo quando os prazeres comuns já estão esgotados pelo excesso.

Enfim, a filosofia lúbrica de Sade faz da destruição um ato criador; submete a moral, o político e o estético à dimensão erótica; utiliza-se do principio de ordenação para potencializar o gozo; faz da exceção um particularização em meio ao excesso enquanto a palavra sempre "convida à ação do corpo". Daí a afirmativa de Octavio Paz quando declara que o erotismo, assim com o Mal em Sade, não postula um principio único, mas uma dispersão ${ }^{11}$.

Se Roland Barthes, em o prazer do texto, escreve "por subtração", porque não encontra as palavras que deseja, e Drummond eleva a poesia mais rica a "um sinal de menos", Sade, por sua vez, escreve como forma de suplementação do gozo, o mais-gozar. Assim realiza a irrealização do mundo, ao mesmo tempo que ascende, mediante a palavra que convoca a ação, ao desejo "pleno" que jamais se realizada de todo, pois sempre se choca com o mais ainda, que não recobre a ferida e nem a contém, embora a sustente.

A fantasmagorização do princípio de ordenação em Athur Bispo do Rosário

O homem vive entre fantasmas e está condenado a alimentá-los com seu sangue porque ele próprio é um fantasma: só encarna ao contato dos fantasmas que engendram seu desejo.

Octavio Paz

É bastante significativa a epígrafe de abertura do livro $A$ memória das coisas: ensaios de literatura, cinema e artes plásticas, de Maria Esther Maciel: "Toda ordem é precisamente uma situação oscilante à beira do precipício (Walter Benjamin)".

Muitos dos textos que compõem $A$ memória das coisas lidam diretamente com o princípio de ordenação e seus sistemas de classificação do mundo utilizados por diferentes escritores, cineastas e artistas, tais como Jorge Luis Borges, Peter Greenaway, Georges Perec, Carlos Drummond de Andrade e Arthur Bispo do Rosário.

Como foi visto, Sade recorre ao excesso e ao princípio de ordenação para potencializar o gozo. Diferentemente, a "ordem" e os procedimentos

${ }^{11}$ Diz Paz: "Uma a uma, as construções de Sade se derrubam. Nada exterior as derruba: o dinamitador é seu próprio pensamento. Sade nega Deus, as morais, as sociedades, o homem, a natureza. Ele nega a si próprio e desaparece por trás de sua gigantesca negação. O Não de Sade é tão grande quanto o Sim de santo Agostinho." Cf. PAZ, 1999, p. 90. 
taxonômicos presentes nos textos analisados por Maria Esther Maciel funcionam mais como eficientes dispositivos que denunciam a falência de suas próprias modalidades classificatórias e de ordenação do mundo. Dito de outra maneira, o mundo é caotizado pelo exacerbamento de suas próprias regras de organização, de classificação exaustiva ou pelo afã das apreensões totalizadoras.

Para tanto, Esther Maciel recorre a textos de autores que focalizam as diferentes maneiras de uso de catálogos, cartas, diários, listas, índices, glossários, aforismos, verbetes, mapas, levantamentos estatísticos, bem como outras formas textuais híbridas que interrompem a redução do inusual e paralisam os processos migratórios do texto para "territórios mais referenciais".

As modalidades de composição e os critérios provisórios de ordem variam imensamente entre os textos analisados por Maria Esther Maciel. A propósito de Georges Perec, por exemplo, a autora destaca os arranjos insólitos de organização dos objetos e as estatísticas absurdas com o intuito de parodiar "a lógica burocrática das instituições" 12 .

Em relação ao conto "Funes, o memorioso", de Jorge Luis Borges, Esther Maciel ressalta a ineficácia da memória absoluta e da percepção infalível do personagem Irineu Funes. Justamente por ser incapaz de esquecer, o personagem ostenta um "prodigioso catálogo de recordações", um inventário de tudo o que foi visto, lido ou imaginado. Essa memória empanturrada dos ínfimos detalhes, ao invés de favorecer a vida do personagem coloca-o numa situação de absurdidade diante da existência: "Não só lhe custava compreender que o símbolo genérico "cão" abrangesse tantos indivíduos díspares de diversos tamanhos e diversa forma; aborreciao que o cão das três e quatorze (visto de perfil) tivesse o mesmo nome que o cão das três e quarto (visto de frente)" ${ }^{13}$.

A memória abarrotada de Funes, sem os processos que operam a seleção, os cortes, as misturas, os lapsos, as falhas e as reduções que toda generalização implica, acaba por se tornar um imenso "despejadouro de lixos", como diz o narrador. Esther Maciel também pontua o mesmo gesto irônico de Borges em um de seus contos mais conhecidos "A Biblioteca de Babel", ao evidenciar a insensatez e a insuficiência das tentativas de arquivamento e "categorização exaustiva do conhecimento e das coisas do mundo, visto que todo recenseamento tende, em seus limites, a revelar o caráter do que é naturalmente incontrolável e ilimitado" 14 .

"O universo (que outros chamam a Biblioteca)" é, sem dúvida, o lugar por excelência da grande fantasmagoria borgiana. É lá que se encontram

${ }^{12}$ Cf. MACIEL, 2004, p. 14.

${ }^{13} \mathrm{Cf}$. BORGES, 2000, p. 545. Essa incapacidade de generalizar é ironizada pelo narrador no conto de Borges: "Suspeito, entretanto, que não era muito capaz de pensar. Pensar é esquecer diferenças, é generalizar, abstrair." (Idem, p. 545)

${ }^{14}$ MACIEL, 2004, p. 14. 
os bibliotecários que nascem, vivem e morrem sem sair da Biblioteca, imersos em buscas infindas e obsessivas de referências, tais como o catálogo de catálogos, os livros de profecias ou aqueles com soluções para todos os problemas mundiais. A ironia é ainda maior quando o narrador descreve a natureza "disforme e caótica de quase todos os livros". E mais: livros com apenas três letras repetidas do começo ao fim. "Já se sabe: para uma linha razoável ou uma correta informação, há léguas de insensatas cacofonias, de confusões verbais e de incoerências" ${ }^{15}$.

A premissa anunciada pelos bibliotecários de que "não há, na vasta Biblioteca, dois livros idênticos" só auxilia para multiplicar a heterogeneidade do "caos", acrescido das suposições de milhares de catálogos falsos ou de um livro total. Diz o narrador: "A certeza de que tudo está escrito nos anula ou nos fantasmagoriza".

A solução que encerra o conto, ao se "insinuar" como resposta ao questionamento da infinitude da Biblioteca, não passa de um exercício especulativo típico dos sofistas: "Se um eterno viajante a atravessasse em qualquer direção, comprovaria ao fim dos séculos que os mesmos volumes se repetem na mesma desordem (que, reiterada, seria uma ordem: a Ordem)" ${ }^{16}$.

A Ordem, de tal forma ironizada por Borges com todos os seus excessos especulativos, apenas salienta a observação de Maria Esther Maciel que aponta, no gesto catalogador de Peter Greenaway, um movimento que denuncia "o objetivo ilusório de completude" e critica os princípios legitimadores de organização que "tendem a se tornar fins em si mesmos."

O brasileiro Arthur Bispo do Rosário (1911-1989), também estudado por Maria Esther Maciel, é um dos exemplos mais significativos em que a obra de arte, balizada pelo princípio de ordenação e simetria, se encontra inextrincavelmente associada à existência e a insuficiência de sua repartição em classes.

Consta no Prontuário Médico da Colônia Juliano Moreira, onde Bispo foi internado aos 27 anos de idade, os seguintes dados: indigente, solteiro, brasileiro, naturalidade desconhecida, sem parentes, sem profissão, alfabetizado, antecedentes policiais. Esquizofrenia paranóide. Daí a facilidade de ver, em suas agregações simétricas de objetos, não uma composição com algum valor artístico, mas uma ordenação obsessiva característica do delírio. O próprio Bispo não chama de "arte" seus objetos, assemblages, fardões, faixas, coleções de miniaturas e bordados. Para ele, toda a sua obra se constituía em "registros" para reconstruir o mundo (respondendo ao chamado de uma voz). Destaque especial deve ser dado ao "manto de apresentação", uma indumentária que Bispo apresentaria quando estivesse

\footnotetext{
${ }^{15}$ Cf. BORGES, 2000 , p. 518

${ }^{16}$ Cf. BORGES, 2000 , p. 523.

${ }^{17}$ MACIEL, 2004, p. 21.
} 
na presença de Deus. Segundo Esther Maciel, após o fim de tudo, Bispo repovoaria "a terra com seus 'objetos mumificados' e suas listas infinitas de nomes iniciadas com determinadas letras do alfabeto e imagens em séries bordadas sobre panos ordinários." 18

Em seu trabalho de arqueoleitora, Esther Maciel identifica, na profusão de objetos encadeados simetricamente na vasta obra de Bispo, um ponto que avilta o Mesmo, e sem conjugar lugares, extravasa o dentro e impõe renovados hábitos de leitura. Em meio aos "dejetos do cotidiano", um objeto díspare assalta o princípio de ordenação e lê-se como a exceção no excesso: "Em quase todos os trabalhos de Bispo", observa Maciel, "verificam-se esses pequenos desvios de simetria, sobras e transbordamentos que evidenciam uma lógica peculiar, que rompe com a obviedade das disposições pretensamente regulares ou reguladoras." 19

Trastes e palavras se entrecruzam nas quase mil peças de Arthur Bispo do Rosário. Sapatos velhos, garrafas, latas, cobertores puídos, linhas desfiadas, produtos descartáveis e tantos outros resíduos acompanhados por infamiliares processos de nomeação em que a palavra perde seu valor utilitário. Mas compõe, de forma incontestável, o "Manto de Apresentação" a Deus, outras condições de possibilidade da palavra literária.

Numa das possíveis leituras, as listas de palavras bordadas nos estandartes de Arthur Bispo, não "funciona" como prótese do objeto, pois ela é o próprio objeto-dejeto que não figura o Homem, tampouco se filia a ele. Escreve Bispo "LETRA - filh D'Hom”. Ou, como se vê em seu agrupamento de nomes: "adeus / adem / adaptado / adicionar / adula / advogado / adequada / adjacencias / a / açúcar / açucarei ro / acho / acontece / açores / acidente / aconquista / acé falo / acende / academia / acre / ações / açude / aço / aceite". ${ }^{20}$

Verifica-se, na lista de Bispo, o "pequeno desvio" formulado por Maria Esther, o objeto "a” órfão de palavra, desvencilhado do sentido. LETRA que se esplende e não é subtraída de seu caráter de estranheza. Essa sequência descomunal, de palavras "mumificadas", por certo não apresenta o "encanto exótico" dos aparatos classificatórios dos contos borgianos ou de Wilson

${ }^{18}$ MACIEL, 2004, p. 17. A atividade do bordado tinha um especial significado na vida de Bispo. De acordo com Maria Angélica Melendi, Bispo "desfiou o uniforme azul de doente mental e bordou com essa linha o lençol que o cobria durante o sono." Melendi realça essa forma de escritura que, ao contrário da fluência da tinta, a palavra é amarrada pelo firme gesto da agulha e a "escrita se faz através de furos e nós." Ver BRANCO, 1988, p. 110.

${ }^{19}$ Esther Maciel destaca também que o ato de colecionar, de acordo com o pensamento de Baudrillard, se constitui no gesto que retira o objeto de seu contexto funcional ou histórico, para inseri-lo no enquadre da subjetividade do colecionador. Em relação à obra de Bispo, salienta Esther, percebe-se o contrário. Suas coleções "arrancam o objeto de sua própria inércia, dão-lhe um nome, um lugar e uma história.” Cf. MACIEL, 2004, p. 19.

${ }^{20}$ Cf. BRANCO, 1988, p. 135. 
Bueno. ${ }^{21}$ No entanto, há, na lista de Bispo, uma difícil beleza torneada à Macabéia, em que a indiferencialidade do neutro nulifica o "comum" do lugar e do nome. Ao reverso dos giromas de Bueno, encantados, os $a$-romas de Bispo, inodoros, desconcertam pela vizinhança das "coisas" sem relação, que se entrechocam no espaço passível de ser mobilizado pela formulação matemática: o conjunto de todas as palavras que começam com a letra "a". Mas há que se fender o $e$ da enumeração e sua solidariedade com a cadeia metonímica. As exceções despontam nos processos de fusão e ruptura de palavras: "açucarei ro / aconquista / acé falo". "O absurdo", diz Foucault, "arruína o $e$ da enumeração." 22 contrário também pode ser formulado: o $e$ da enumeração arruína a linha que desaba no absurdo. No entanto, há sempre no tabuleiro das identidades, a casa vazia, o lugar do morto, como proclamou Arthur Bispo: "Cada louco é guiado por um cadáver. O louco só fica bom quando se livra desse morto." ${ }^{23}$

Mas como matar esse morto sem inserí-lo nas superfícies ordenadas do riso burocrático? Se considerarmos que ter um "sistema" é fatal para a mente, como asseverou Schlegel, não tê-lo também é fatal. À maneira do desastre, Blanchot recoloca a indagação em outro espaço de acolhimento: "Existe a questão, mas não desejo de resposta; existe a questão, e nada que pode ser dito, mas justamente esse nada para dizer". ${ }^{24}$

\section{RESUMO}

Este ensaio busca identificar, na escrita do Marquês de Sade e nas peças de Arthur Bispo do Rosário, as diferentes modalidades de uso do princípio de ordenação e da insuficiência dos sistemas de classificação exaustiva do mundo. Para tanto, adotou-se como instância de interlocução teórica algumas das reflexões desenvolvidas por Eliane Robert Moraes Lições de Sade: ensaios sobre a imaginação libertina, e por Maria Esther Maciel em A memória das coisas.

\footnotetext{
${ }^{21} \mathrm{Na}$ enciclopédia chinesa elaborada por Borges, os animais se dividem em: a) pertencentes ao imperador; b) embalsamados; c) domesticados; d) leitões; e) sereias; f) fabulosos; g) cães em liberdade; h) incluídos na presente classificação; i) que se agitam como loucos; j) inumeráveis; k) desenhados com um pincel muito fino de pêlo de camelo; l) et cetera, $m$ ) que acabam de quebrar a bilha; $n$ ) que de longe parecem moscas". Já a miscelânia de Wilson Bueno é exclusivamente da ordem do fabuloso. Os "giromas" de seu jardim zoológico "têm dezenas de olhos sendo que estes também servem para escutar, aspirar o ar e excretar a chuva que bebem, fertilizar-se; já os 'rememorantes', espécies de duendes da noite, são os monstros que, dotados de uma inenarrável memória, que 'nada teme da natureza dos sonhos', devolvem-nos, em forma de fragmentos, lapsos, sobras, os sonhos que esquecemos e que lhes servem de alimento". Cf. MACIEL, Maria Esther. A memória das coisas, 2004, p. 56.

${ }^{22}$ Cf. FOUCAULT, Michel, 1999, XII.

${ }^{23}$ Cf. o ensaio de Maria Angélica Melendi In:BRANCO, 1988, p. 107.

24 "There is a question, but not desire for an answer; there is a question, and nothing that can be said, but just this nothing, to say. Cf. BLANCHOT, 1995, p. 87.
} 
SilVA, R. G. Para AlÉm do PrincíPIo de Ordenação...

Palavras-chave: Marquês de Sade; Arthur Bispo do Rosário; excesso.

\begin{abstract}
This essay focuses on the organization's principle and its excess as an insufficient way of classifying the world, as we can see on Marques de Sade and Arthur Bispo do Rosário's works. These issues are emphasized by the light of Eliane Robert de Moraes and Maria Esther Maciel's thoughts, especially on their books Lições de Sade: ensaios sobre a imaginação libertina and $A$ memória das coisas.
\end{abstract}

Keywords: Marquês de Sade; Arthur Bispo do Rosário; excess.

\title{
REFERÊNCIAS
}

BARTHES, Roland. O prazer do texto. São Paulo: Perspectiva, 2006.

BEAUVOIR, Simone de. Novelas do marquês de Sade. São Paulo: Difusão Européia do Livro, 1961.

BLANCHOT, Maurice. The Writing of the Disaster. London: University of Nebraska Press, 1995.

BORGES, Jorge Luis. Obras completas. São Paulo: Globo, 2000. v. I.

BRANCO, Lucia Castello (Org.). Coisa de louco. Belo Horizonte: Mazza Edições, 1988.

DELEUZE, Gilles; GUATTARI, Félix. O que é a filosofia. Tradução de: Bento Prado Junior e Alberto Alonzo Muñoz. Rio de Janeiro: Editora 34, 1992.

DERRIDA, Jacques. Gramatologia. Tradução de: Miriam Chnaiderman. 2. ed. São Paulo: Perspectiva, 1997.

FOUCAULT, Michel. As palavras e as coisas: uma arqueologia das ciências humanas. Tradução de: Salma Tannus Muchail. 8. ed. São Paulo: Martins Fontes, 1999.

FREUD, Sigmund. Além do princípio de prazer. Tradução de: Christiano Monteiro Oiticica. Rio de Janeiro: Imago Editora LTDA, 1976.

LACAN, Jacques. Escritos. Tradução de: Vera Ribeiro. Rio de Janeiro: Zahar, 1998.

LAUTRÉAMONT, Conde de. Os cantos de Maldoror. Tradução de: Claudio Willer. São Paulo: Iluminuras, 2005.

MACIEL, Maria Esther. A memória da coisas: ensaio sobre literatura, cinema e artes plásticas. Rio de Janeiro: Lamparina editora, 2004.

MORAES, Eliane Robert. Lições de Sade: ensaios sobre a imaginação libertina. São Paulo: Iluminuras, 2006. 
PAZ, Octavio. Um mais além erótico: Sade. Tradução de; Wladir Dupont. São Paulo: Mandarim, 1999.

SADE, Marquês de. Os 120 dias de Sodoma, ou A Escola da libertinagem. Tradução de: Alain François. São Paulo: Iluminuras, 2006. 2003. A filosofia na alcova. Tradução de: Contador Borges. 3. ed. São Paulo: Iluminuras, . Justine: os sofrimentos da virtude. São Paulo: Círculo do Livro, 1988.

Submetido em: 18/12/2007.

Aceito em: 31/03/2009. 